\title{
Effect of Dietary Protein Depletion and Ethanol on Demethylation and Denitrosation of $N$-nitrosodimethylamine by Rabbit Liver Microsomes
}

\author{
Hirofumi SUZUKI, ${ }^{1}$ Masatoshi KAKU, ${ }^{1}$ Seiki HORI, ${ }^{1}$ \\ and Takashi SHIMOYAMA ${ }^{2}$ \\ ${ }^{1}$ First Department of Physiology, ${ }^{2}$ Fourth Department of \\ Internal Medicine, Hyogo College of Medicine, \\ Mukogawa-cho, Nishinomiya, \\ Hyogo 663, Japan
}

(Received October 22, 1990)

Summary To study how the metabolism of $N$-nitrosodimethylamine (NDMA) is affected by dietary protein level and chronic ethanol feeding, 24 rabbits at 18 weeks of age, assigned to four groups, each with 6 rabbits, were fed for 8 weeks on the following 4 different diets; $21 \%$ protein content containing $21.1 \%$ casein and water, $21 \%$ protein content containing $21.1 \%$ casein and $7.5 \%$ ethanol, $7 \%$ protein content containing $4.8 \%$ casein and water, $7 \%$ protein content containing $4.8 \%$ casein and $7.5 \%$ ethanol. Body weights, liver weights and microsomal protein contents in the liver were significantly smaller in $7 \%$ protein diet groups than in 21\% protein diet groups. Microsomal P-450 contents per protein content were less in $7 \%$ protein diet groups than in $21 \%$ protein diet groups. NDMA demethylation activity due to non-arachidonic acid stimulated system (NASS) and NDMA denitrosation activity were greater in $21 \%$ protein diet groups than in $7 \%$ diet groups. Chronic ethanol feeding increased NDMA denitrosation activity due to arachidonic acid stimulated system in both dietary protein levels. The ratio of NDMA demethylation activity (carcinogenic action) to NDMA denitrosation activity (detoxication action) was greater in $7 \%$ dietary protein groups than $21 \%$ dietary protein groups. The value of this ratio was decreased by chronic ethanol feeding in 7\% dietary protein groups. Cytotoxic and carcinogenic actions of NDMA might be enhanced by low protein diet due to inhibition of denitrosation of NDMA in liver microsome and chronic $7.5 \%$ ethanol feeding alleviates metabolic activation of NDMA to carcinogenic compounds.

Key Words $N$-nitrosodimethylamine, cytochrome P-450, demethylation, denitrosation, protein, ethanol, rabbit liver microsome 
$N$-nitrosodimethylamine (NDMA) has been shown to be a potent hepatocarcinogen in many animals and a suspected carcinogen in human beings (1). It is known that NDMA is metabolized by two routes in the liver. One is the activation of NDMA to a mutagen or an ultimate carcinogen for mammalian cells by the demethylation of the $\alpha$ carbon catalyzed mainly by a P-450-dependent metabolic pathway $(2,3)$.

The other is the enzymatic denitrosation of NDMA. The denitrosation route of NDMA is presumed to be an inactivation pathway of the carcinogenicity of NDMA $(4,5)$. These two competing pathways by which NDMA is metabolized have been shown to be present in the liver microsomes. The liver is considered to be the primary organ capable of metabolizing ethanol. The main pathways for ethanol metabolism in the liver are catalyzed by the microsomal ethanol oxidizing system (MEOS) and alcohol dehydrogenase. MEOS is reconstructed by the liver microsome P-450, NADPH-cytochrome $c$ reductase and phospholipids. It is known that the activity of MEOS is enhanced by chronic alcohol administration in the rats $(6,7)$. It has been reported, however, that the content of P-450 in the liver changes according to dietary protein level $(8-11)$. There are many kinds of P-450 in the liver and they metabolize xenobiotics such as NDMA and ethanol as well as endobiotics (12). Since excess intake of ethanol has a variety of toxic effects on the liver such as functional and morphological alterations accompanied by fatty liver and liver cirrhosis, and many enzymatic activities in the liver are affected by changes in dietary protein level (13-15). It is thus of interest to study the effect of dietary protein level on the changes in P-450 content, activities of denitrosation and demethylation of NDMA in the liver induced by the intake of ethanol.

\section{MATERIALS AND METHODS}

Animals and diets. Twenty-four male white rabbits fed on commercial rabbit food were used for the experiment and studies were commenced at age of 17 weeks. All rabbits were housed individually in a plastic metabolic cage in a light controlled room ( $12 \mathrm{~h} \mathrm{light)}$ at $25^{\circ} \mathrm{C}$. They were fed on rabbit food from Clea Japan CE2 for a week and divided into 4 groups of 6 rabbits each and fed on diets with different protein level and drinks for 8 weeks. The following diets and drinks were offered to the rabbits, $21 \%$ protein content containing $21.1 \%$ casein and distilled water $(21$ C group), $21 \%$ protein content containing $21.1 \%$ casein and $7.5 \%$ ethanol $(21 \mathrm{E}$ group), $7 \%$ protein content containing $4.8 \%$ casein and distilled water (7 C group), and 7\% protein content containing $4.8 \%$ casein and $7.5 \%$ ethanol (7E group). All rabbits were allowed free access to food and drink.

The composition of the experimental diet is given in Table 1. At 26 weeks of age, rabbits were sacrificed by injection of air into the ear vein after fasting for $12 \mathrm{~h}$. Livers were removed as soon as possible and blood in the liver was drawn immediately after removal by perfusion through the portal vein with cold $1.15 \%$ $\mathrm{KCl}$ solution. Livers were weighed, minced and homogenized in a fourfold volume 
Table 1. Composition of experimental diet.

\begin{tabular}{|c|c|c|c|c|}
\hline Group & $21 \mathrm{C}$ group & $21 \mathrm{E}$ group & $7 \mathrm{C}$ group & $7 \mathrm{E}$ group \\
\hline Protein levels (\%) & $20.97(\%)$ & $20.97(\%)$ & $7.03(\%)$ & $7.03(\%)$ \\
\hline Drink & D.D.W. & $\begin{array}{c}7.5(\mathrm{v} / \mathrm{v}) \% \\
\text { EtOH }\end{array}$ & D.D.W. & $\begin{array}{c}7.5(\mathrm{v} / \mathrm{v}) \% \\
\text { EtOH }\end{array}$ \\
\hline Casein & \multicolumn{2}{|c|}{21.1} & \multicolumn{2}{|r|}{4.8} \\
\hline Corn starch & \multicolumn{2}{|c|}{25.3} & \multicolumn{2}{|c|}{41.6} \\
\hline Ocenol & \multicolumn{2}{|c|}{2} & \multicolumn{2}{|c|}{2} \\
\hline Alfalfa & \multicolumn{2}{|c|}{10} & \multicolumn{2}{|c|}{10} \\
\hline Corn & \multicolumn{2}{|c|}{15} & \multicolumn{2}{|r|}{15} \\
\hline Avicel & \multicolumn{2}{|c|}{7.5} & \multicolumn{2}{|r|}{7.5} \\
\hline Soybean oil & \multicolumn{2}{|r|}{3.5} & \multicolumn{2}{|r|}{3.5} \\
\hline $\mathrm{CaCO}_{3}$ & \multicolumn{2}{|r|}{1.5} & \multicolumn{2}{|r|}{1.5} \\
\hline $\mathrm{Ca}_{3}\left(\mathrm{PO}_{4}\right)_{2}$ & \multicolumn{2}{|r|}{2} & \multicolumn{2}{|r|}{2} \\
\hline $\mathrm{NaCl}$ & \multicolumn{2}{|r|}{1.1} & \multicolumn{2}{|r|}{1.1} \\
\hline Mix. of vitamins & \multicolumn{2}{|c|}{1} & \multicolumn{2}{|r|}{1} \\
\hline Mix. of minerals & \multicolumn{2}{|c|}{10} & \multicolumn{2}{|c|}{10} \\
\hline Total & \multicolumn{2}{|c|}{$100(\%)$} & \multicolumn{2}{|c|}{$100(\%)$} \\
\hline
\end{tabular}

$21 \mathrm{C}=21 \%$ protein, deionized distilled water (control) diet; $21 \mathrm{E}=21 \%$ protein, ethanol diet; $7 \mathrm{C}=7 \%$ protein, deionized distilled water (control) diet; $7 \mathrm{E}=7 \%$ protein, ethanol diet. EtOH: ethanol. D.D.W.: deionized distilled water.

of ice-cold $0.3 \mathrm{M}$ sucrose, $0.1 \mathrm{M}$ potassium phosphate buffer ( $\mathrm{pH} 7.5)$ containing 10 mM EDTA, $0.25 \mathrm{mM}$ phenylmethyl-sulfonyl fluoride (PMSF) and $0.1 \%$ cholic acid. The homogenate was centrifuged at $10,000 \times g$ for $20 \mathrm{~min}$. The supernatant fractions thus obtained were centrifuged at $100,000 \times g$ for $60 \mathrm{~min}$.

Pellets were suspended in $1.15 \% \mathrm{KCl}$ solution containing $2 \mathrm{mM}$ EDTA, $50 \mathrm{mM}$ potassium phosphate buffer ( $\mathrm{pH} 7.5)$ and $0.1 \%$ cholic acid. The microsomes in this suspension were prepared by centrifugation at $100,000 \times g$ for $40 \mathrm{~min}$.

The microsomes were suspended in $20 \%$ glycerol containing $0.1 \mathrm{M}$ potassium phosphate buffer (pH 7.5), $10 \mathrm{mM}$ EDTA and $0.1 \mathrm{mM}$ PMSF and stored at $-80^{\circ} \mathrm{C}$.

Operation was performed at 0 to $4^{\circ} \mathrm{C}$ according to previously reported procedures $(16,17)$ with some modifications.

The microsomes were used for enzyme assay within 2 days following the day of preparation. Microsomal protein content was determined by the method of Lowry et al. (18), with bovine serum albumin as standard. P-450 concentrations in the microsomes and content of cytochrome $b_{5}$ were determined by the method of Omura and Sato (19). The activities of NADPH-cytochrome P-450 reductase $\left(\mathrm{FP}_{2}\right)$ were measured by the method of Taniguchi et al. (20). The microsomal NDMA demethylase activity was determined by measuring the production of formaldehyde (HCHO). To estimate the NDMA demethylase activity due to a non-arachidonic acid stimulated system, the assay mixture in a total volume of 0.5 
$\mathrm{ml}$ containing $1 \mathrm{mg}$ (protein) microsome, $250 \mathrm{mM}$ NDMA, $2 \mathrm{mM}$ NADPH, $100 \mathrm{mM}$ Tris-HCl buffer ( $\mathrm{pH} \mathrm{8.5)}$ was incubated at $37^{\circ} \mathrm{C}$ for $20 \mathrm{~min}$. The reaction was terminated by adding $0.2 \mathrm{ml}$ of $80 \%$ trichloroacetic acid to the assay mixture. Then the mixture was centrifuged at $700 \times g$ for $10 \mathrm{~min}$. An aliquot containing $0.4 \mathrm{ml}$ of the supernatant was used for formaldehyde estimation. Content of formaldehyde was measured by the method of Nash (21). Blanks were prepared in the absence of microsome in the assay mixture or by adding $0.2 \mathrm{ml}$ of $80 \%$ trichloroacetic acid to the assay mixture before incubation. To estimate NDMA demethylation activity due to the arachidonic acid stimulated system, the assay mixture containing $1 \mathrm{mg}$ (protein) microsome, $50 \mathrm{mM}$ NDMA, $0.1 \mathrm{mM}$ NADPH, $200 \mu \mathrm{M}$ arachidonic acid and $100 \mathrm{mM}$ Tris- $\mathrm{HCl}$ buffer $(\mathrm{pH} 8.75)$ in $0.5 \mathrm{ml}$ was incubated at $37^{\circ} \mathrm{C}$ for $1.5 \mathrm{~min}$.

The microsomal NDMA denitrosation activity was determined by measuring the production of nitrite $\left(\mathrm{NO}_{2}{ }^{-}\right)$. The assay mixture containing $1 \mathrm{mg}$ (protein) microsome, $70 \mathrm{~mm}$ NDMA, $0.3 \mathrm{mM}$ NADPH and $100 \mathrm{mM}$ Tris-HCl buffer (pH 8.25 ) in a total volume of $0.5 \mathrm{ml}$ was used for the determination of NDMA denitrosation activity due to non-arachidonic acid stimulated system.

The mixture was incubated at $37^{\circ} \mathrm{C}$ for $1 \mathrm{~min}$ and the reaction was terminated by adding $200 \mu 1$ of $80 \%$ trichloroacetic acid. The mixture was centrifuged at $700 \times g$ for $10 \mathrm{~min}$. An aliquot containing $0.4 \mathrm{ml}$ of the supernatant was mixed with $0.1 \mathrm{ml}$ of a nitrite reagent containing $1.65 \%$ sulfanilic acid, $10 \%$ acetic acid and $0.05 \% N$-1-naphthylethylenediamine. This reaction mixture was centrifuged at $700 \times g$ for $10 \mathrm{~min}$.

The mixture was centrifuged at $700 \times g$ for $10 \mathrm{~min}$ in the dark room. To estimate the content of nitrite in the supernatant, absorbance of the supernatant at $545 \mathrm{~nm}$ was measured. The assay mixture containing $1 \mathrm{mg}$ (protein) microsome, $150 \mathrm{mM}$ NDMA $0.1 \mathrm{mM}$ NADPH, $200 \mu \mathrm{M}$ arachidonic acid and $100 \mathrm{mM}$ Tris- $\mathrm{HCl}$ buffer ( $\mathrm{pH} 7.75$ ) in a total volume of $0.5 \mathrm{ml}$ was used for determination of NDMA denitrosation activity due to the arachidonic acid stimulated system. The assay mixture was incubated at $37^{\circ} \mathrm{C}$ for $4 \mathrm{~min}$.

\section{RESULTS}

The initial and final body weights, weight gain during the experiment, liver weight, the ratio of liver weight to body weight and liver microsomal protein content at the end of the experiment in four groups are presented in Table 2.

Body weight of $7 \%$ protein feeding groups decreased during the experiment period and the body weights of $21 \%$ protein feeding groups at the end of the experiment were significantly greater than those of $7 \%$ protein feeding groups.

No significant effect of ethanol on the growth of rabbits was observed in both $7 \%$ protein feeding groups and 21\% protein feeding groups. However, body weight gains of chronic alcohol feeding groups tended to be smaller than those of control groups in both $7 \%$ and $21 \%$ protein feeding groups.

Liver weights of $21 \%$ protein feeding groups were significantly greater than 
Table 2. Effects of chronic alcohol feeding on body weight, liver weight and liver microsomal protein content in $21 \%$ and $7 \%$ protein feeding rabbits.

\begin{tabular}{lllll}
\hline & $21 \mathrm{C}$ group & $21 \mathrm{E}$ group & $7 \mathrm{C}$ group & $7 \mathrm{E}$ group \\
\hline $\begin{array}{c}\text { Body weight before } \\
\text { exp. feed (kg) }\end{array}$ & $2.32 \pm 0.12$ & $2.52 \pm 0.17$ & $2.88 \pm 0.17$ & $2.93 \pm 0.21$ \\
$\begin{array}{c}\text { Body weight after } \\
\text { exp. feed (kg) }\end{array}$ & $3.42 \pm 0.16^{* * P}$ & $3.26 \pm 0.12^{* * P}$ & $2.64 \pm 0.17$ & $2.55 \pm 0.19$ \\
$\begin{array}{c}\text { Change of body } \\
\text { weight (\%) }\end{array}$ & $+(49.7 \pm 11.6)^{* * P}$ & $+(31.5 \pm 8.3)^{* * P}$ & $-(10.9 \pm 3.8)$ & $-(12.4 \pm 4.6)$ \\
$\begin{array}{c}\text { Liver weight after } \\
\text { exp. feed (g) }\end{array}$ & $82.2 \pm 7.5^{* * P}$ & $81.5 \pm 8.4^{* * P}$ & $65.3 \pm 4.3$ & $57.6 \pm 7.2$ \\
$\begin{array}{c}\text { Liver weight/Body } \\
\text { weight (\%) }\end{array}$ & $2.58 \pm 0.13$ & $2.22 \pm 0.25$ & $2.39 \pm 0.11$ & $2.50 \pm 0.22$ \\
$\begin{array}{c}\text { Ms protein content } \\
\text { (mg/g liver) }\end{array}$ & $8.77 \pm 1.57$ & $9.22 \pm 1.57$ & $6.60 \pm 1.13$ & $7.16 \pm 1.15$ \\
$\begin{array}{c}\text { Ms protein content } \\
\text { (mg/whole liver) }\end{array}$ & $723.9 \pm 151.6^{* * P}$ & $745.5 \pm 133.8^{* * P}$ & $425.6 \pm 67.2$ & $383.1 \pm 46.6$ \\
\hline
\end{tabular}

Values represent the mean \pm SEM. $* P$ : Significant differences between $21 \%$ and $7 \%$ protein feeding groups. ${ }^{* * P}<0.01$. Ms: microsome, exp. feed: experimental feeding.

those of $7 \%$ protein feeding groups. Chronic ethanol feeding decreased considerably liver weight of rabbits fed on $7 \%$ protein diet. However this difference was statistically not significant. No significant differences in the ratio of liver weight to body weight were observed among the four groups.

Microsomal protein contents per whole liver were significantly greater in $21 \%$ protein feeding groups than in $7 \%$ protein feeding groups. Contents of microsomal protein per liver weight for $21 \%$ protein feeding groups were considerably greater than those for $7 \%$ protein feeding groups. However these differences were statistically not significant. No significant differences in this ratio were found between chronic ethanol feeding groups and controls in both $21 \%$ and $7 \%$ protein feeding groups.

Contents of P-450 and cytochrome $b_{5}, \mathrm{FP}_{2}$ activity and those corrected for microsomal protein contents in the four groups are presented in Fig. 1A and Fig. 1B. P-450 contents per whole liver and per $1 \mathrm{mg}$ microsomal protein for $21 \%$ protein feeding groups were significantly greater than those for $7 \%$ protein feeding groups. However these values were not influenced by chronic ethanol feeding in both $21 \%$ and $7 \%$ protein feeding groups. $\mathbf{F P}_{2}$ activities for whole liver were highest in 7\% protein diet and water feeding group and lowest in 7\% protein diet and chronic ethanol feeding group. In $21 \%$ protein diet groups, $\mathbf{F P}_{2}$ activity for whole liver was reduced slightly by chronic ethanol feeding.

$\mathbf{F P}_{2}$ activities for microsomal protein contents were significantly greater in $7 \%$ protein feeding groups than in $21 \%$ protein feeding groups. In both $21 \%$ and $7 \%$ protein feeding groups, chronic ethanol feeding decreased $\mathrm{FP}_{2}$ activity per micro- 
A
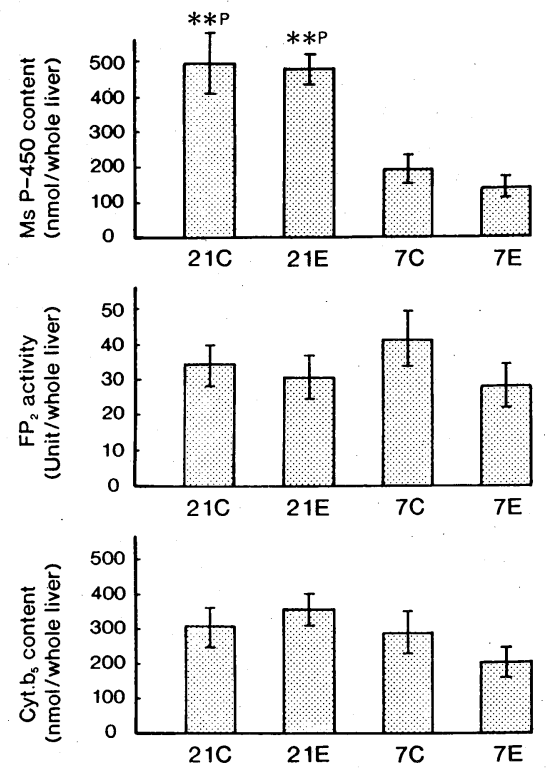

B
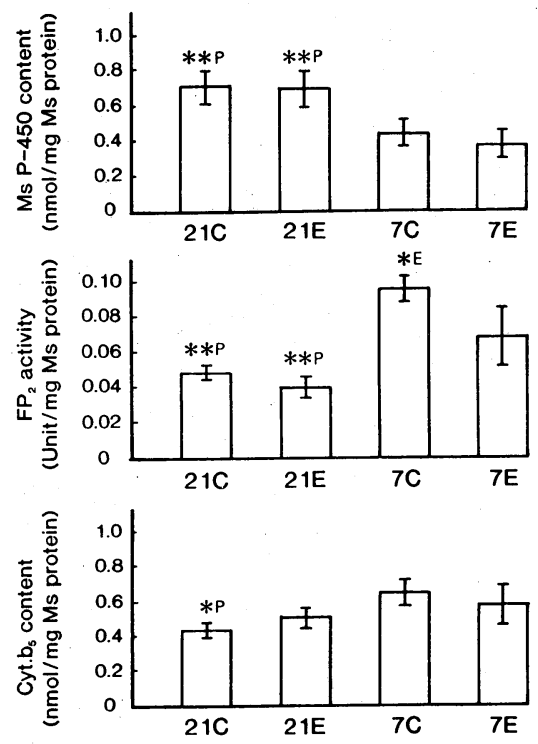

Fig. 1. Effects on hepatic microsomal P-450 system by chronic alcohol feeding in $21 \%$ and $7 \%$ protein feeding rabbits. A: content or activity of P-450 linked system per whole liver 1 mg microsomal protein $\square$. Values are means \pm SEM. $* P$ : Significant differences between $21 \%$ and $7 \%$ protein feeding groups. ${ }^{*} E$ : Significant differences between water and ethanol feeding in groups of the same dietary protein. ${ }^{* *} \boldsymbol{P}<$ $0.01,{ }^{*} P<0.05$. ${ }^{*} E<0.05$. Ms: microsome, P-450: cytochrome P-450, $\mathrm{FP}_{2}$ : NADPH cytochrome P-450 reductase, Cyt. $b_{5}$ : cytochrome $b_{5}$.

somal protein content.

NDMA demethylation activites (DM) and NDMA denitrosation activities (DN) for whole liver due to arachidonic acid stimulated system (ASS) and nonarachidonic acid stimulated system (NASS) were shown in Fig. 2A and Fig. 2B.

DM-NASS for $21 \%$ protein feeding groups was significantly greater than that for $7 \%$ protein feeding groups while DM-ASS for $21 \%$ protein feeding groups was considerably smaller than that for $7 \%$ protein feeding groups. Chronic ethanol feeding increased DM-NASS in 21\% protein feeding groups and decreased slightly both DM-NASS and DM-ASS in 7\% protein feeding groups. DN-NASS and DN-ASS were significantly greater in $21 \%$ protein feeding groups than in $7 \%$ protein feeding groups. In $21 \%$ protein feeding groups, DN-ASS was increased by chronic ethanol feeding. DN-NASS and DN-ASS were increased by chronic ethanol feeding in 7\% protein feeding groups. These changes induced by chronic ethanol feeding were statistically significant.

According to two-way analysis of variance, the mutual effect of chronic 
A

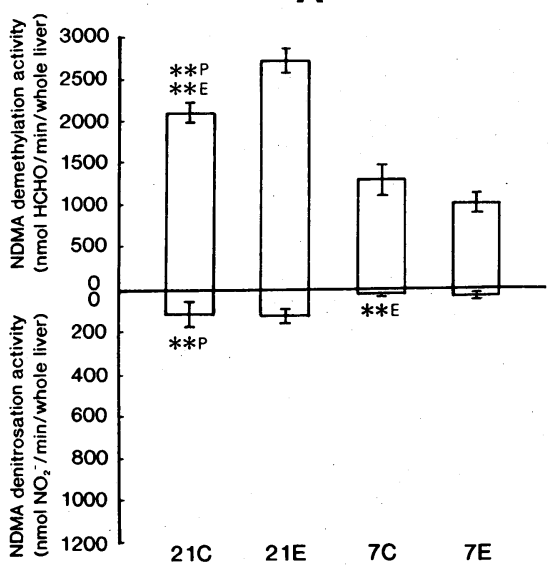

B

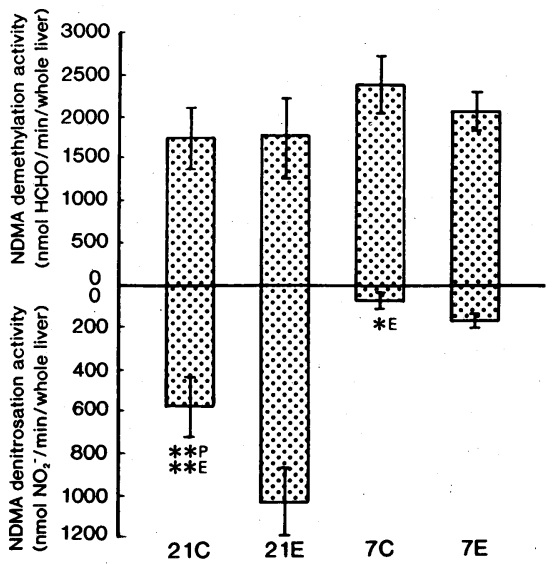

Fig. 2. Effects of chronic alcohol feeding and different dietary protein levels on NDMA demethylation and denitrosation activities of rabbit liver microsomes. A: non-arachidonic acid stimulated system $\square$. B: arachidonic acid stimulated system value represents the mean $\pm \operatorname{SEM}(n=6)$. *P: Significant differences between $21 \%$ and $7 \%$ protein feeding groups. $*_{E}$ : Significant differences between water and ethanol feeding in groups of the same dietary protein. ${ }^{* *} P<0.01$. ${ }^{* *} E<$ $0.01,{ }^{*} E<0.05$. NDMA: $N$-nitrosodimethylamine. Ms: Microsome.

ethanol feeding and different dietary protein level on NDMA denitrosation activity in ASS was significant.

NDMA demethylation activity and NDMA denitrosation activity due to NASS and ASS based on microsomal protein content were shown in Fig. 3A and Fig. 3B. DM-ASS for $21 \%$ protein feeding groups was significantly smaller than that for $7 \%$ protein feeding groups. DN-NASS was highest in $21 \%$ protein and ethanol feeding group. DN-NASS and DN-ASS were significantly greater in $21 \%$ protein feeding groups than in $7 \%$ protein feeding groups. These activities were increased by chronic ethanol feeding in $7 \%$ and $21 \%$ protein feeding groups. Among these differences, an increase in DN-NASS and DN-ASS in $7 \%$ protein feeding groups induced by chronic ethanol feeding was statistically significant.

\section{DISCUSSION}

The liver has many complex functions in the metabolism of protein, ethanol and other nutrients and these functions are affected by chronic ethanol feeding and different dietary protein level.

In the present study, there were no differences in plasma constituents, including plasma protein level and transaminases, between water feeding groups and chronic ethanol feeding groups, though caloric intake tended to be decreased by 
A

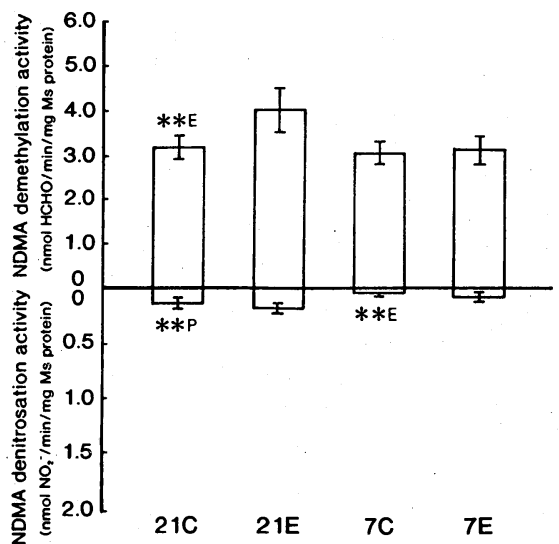

B

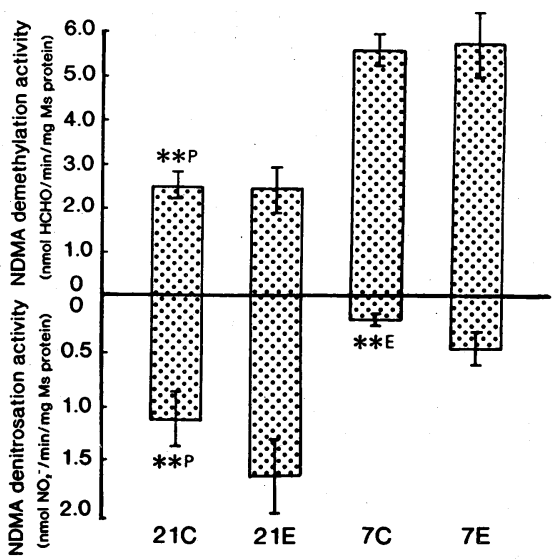

Fig. 3. Effects of chronic alcohol feeding and different dietary protein levels on NDMA demethylation and denitrosation activities by rabbit liver microsomes. A: non-arachidonic acid stimulated system $\square$. B: arachidonic acid stimulated system Each value represents the mean \pm SEM $(n=6)$. * $*$ : Significant differences between $21 \%$ and $7 \%$ protein feeding groups. ${ }^{*} E$ : Significant differences between water and ethanol feeding in groups of the same dietary protein. $* * P<0.01$. ${ }^{* *} E<0.01$. NDMA: $N$-nitrosodimethylamine. Ms: Microsome.

chronic ethanol feeding (data were not presented).

Thus it can be said that changes in protein metabolism induced by chronic ethanol feeding in both $7 \%$ and $21 \%$ protein groups were small.

The decrease of dietary protein intake resulted in the greater changes in plasma constituents (data were not presented) and enzymes in the liver than chronic ethanol feeding. Therefore it is considered that changes in hepatic functions and ethanol metabolism induced by decrease of dietary protein level may be somewhat responsible for the effects of chronic ethanol feeding observed in the present experiment. However, differences in hepatic enzymes between water feeding groups and ethanol feeding groups were so great that most of the changes found between these two groups were caused by chronic ethanol feedings, though some changes were associated with difference in dietary protein level.

It is known that dietary protein level affects the metabolism of NDMA in the liver by changes in hepatic microsomal enzyme activities including P-450. As shown in Table 2, Fig. 1A and Fig. 1B, dietary protein deficiency for 8 weeks caused a significant decrease in body weight, liver weight, microsomal protein content, microsomal P-450 content per microsomal protein content and liver.

These results suggest that NDMA was metabolized more slowly in the liver by P-450 in rabbits fed a low-protein diet. It is known that both $\mathbf{F P}_{2}$ activity and cytochrome $b_{5}$ are essential for the metabolizing activity with P-450 $(20,22)$. FP 
activity and cytochrome $b_{5}$ content per microsomal protein in $7 \%$ protein diet groups were considerably greater than those in $21 \%$ protein diet groups. Thus it is possible that the enzymatic activity of metabolizing NDMA per P-450 content might be enhanced by the increase in electron transport due to $\mathbf{F P}_{2}$ activity and cytochrome $b_{5}$ in $7 \%$ protein diet groups.

The hepatic P-450 is induced by many chemicals and the P-450 system is composed of many isozymes with overlapping substrate specificity $(23,24)$. It is assumed that the rabbit hepatic P-450 is induced by chronic ethanol feeding and some of P-450 thus induced are capable of metabolizing NDMA in the liver.

In the present study, microsomal $\mathrm{P}-450$ content, $\mathrm{FP}_{2}$ activity and cytochrome $b_{5}$ content per liver did not change, but NDMA demethylation activity and NDMA denitrosation activity were enhanced by chronic alcohol feeding in $21 \%$ protein diet groups. Since metabolism of NDMA was determined mainly by P-450 activity instead of $\mathbf{F P}_{2}$ activity and amount of cytochrome $b_{5}$ content, these results suggested that P-450 content concerning metabolism of NDMA was increased and other kinds of P-450 isozymes were decreased by chronic ethanol feeding in $21 \%$ protein diet group. Induction of $\mathrm{P}-450, \mathrm{FP}_{2}$ and cytochrome $b_{5}$ by chronic ethanol feeding was impaired by low-protein feeding, and this impairment may be attributed to protein deficiency induced by a diet containing $7 \%$ protein as compared to $21 \%$ protein diet in the control.

Metabolism of arachidonic acid and prostaglandins by P-450 have been studied extensively by many investigators (25-28). According to these investigations, it is expected that the metabolism of NDMA may be related to that of arachidonic acid. The microsomal NDMA metabolizing system can be separated from arachidonic acid stimulated system and non-arachidonic acid stimulated system $(29,30)$.

As shown in Fig. 2A and Fig. 2B, NDMA demethylation activity due to arachidonic acid stimulated system was greater in 7\% protein diet groups than in $21 \%$ protein diet groups while NDMA denitrosation activity in both arachidonic acid stimulated and non-arachidonic acid stimulated systems was greater in $21 \%$ protein diet groups than 7\% protein diet groups. Chronic ethanol feeding tended to increase NDMA denitrosation activity in both systems. Particularly, NDMA denitrosation activity in both NASS and ASS systems was significantly augmented by $7.5 \%$ chronic ethanol feeding in $7 \%$ protein diet groups. These results clearly indicate that not only diet protein level but also ethanol feeding affects the metabolism of NDMA due to denitrosation in the liver.

The metabolic activation of NDMA to cytotoxic, mutagenic and carcinogenic metabolites occurs by the demethylation process, while the denitrosation of NDMA is considered to be detoxication process. These two metabolic pathways might be competing in the metabolism of NDMA. Thus, the ratio of NDMA demethylation to denitrosation activity may be related to cytotoxic and genotoxic action of NDMA. This ratio in four groups was shown in Fig. 4A and Fig. 4B. The ratio of NDMA demethylation activity to NDMA denitrosation activity was greater in $7 \%$ protein diet groups than in $21 \%$ protein diet groups, and chronic ethanol 
A

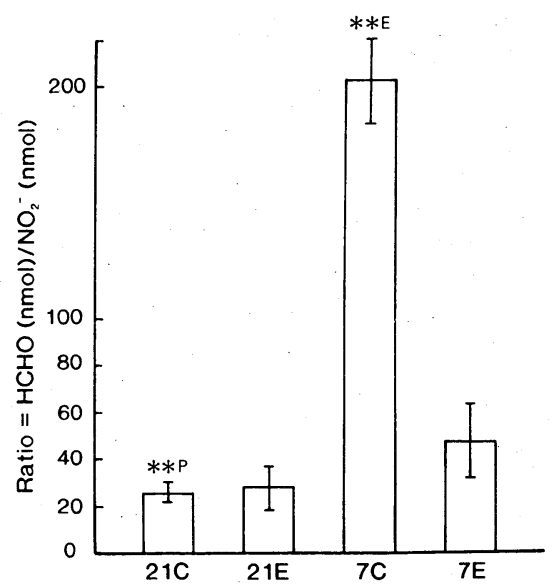

B

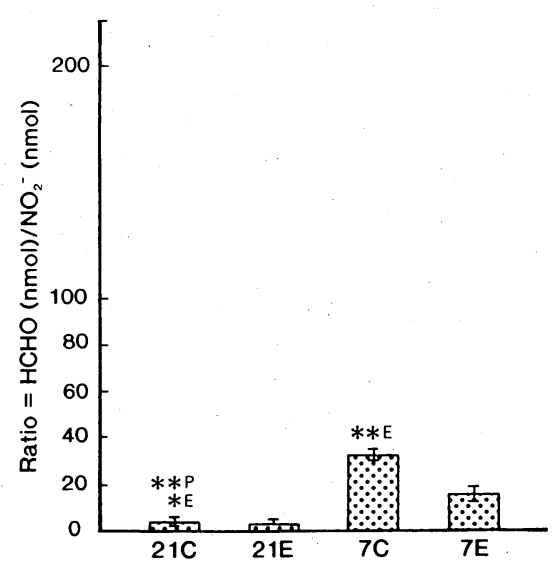

Fig. 4. The ratio of NDMA demethylation activity to NDMA denitrosation activity in rabbit liver microsomes. A: non-arachidonic acid stimulated system $\square$. B: arachidonic acid stimulated system ni: Values expressed as $\mathrm{HCHO} \mathrm{nmol} /$ $\mathrm{NO}_{2}{ }^{-}$nmol. Each value represents the mean \pm SEM $(n=6)$. $* P$ : Significant differences between $21 \%$ and $7 \%$ protein feeding groups. ${ }^{*} E$ : Significant differences between water and ethanol feeding in groups of the same dietary protein. ${ }^{* *} \boldsymbol{P}<0.01$. ${ }^{* *} E<0.01,{ }^{*} E<0.05$.

feeding decreased this ratio in $7 \%$ protein diet groups.

According to two-way analysis of variance, mutual effect of chronic ethanol feeding and difference in 7\% protein diet and $21 \%$ protein diet on the ratio of NDMA demethylation activity to NDMA denitrosation activity was significant.

These results might indicate cytotoxic and carcinogenic actions of NDMA were enhanced by protein deficiency in rabbits and chronic $7.5 \%$ ethanol feeding alleviates cytotoxic effect of NDMA in protein deficient rabbits. Further systematic studies are necessary to elucidate the effect of dietary protein level and chronic ethanol feeding on the NDMA metabolism in the liver.

\section{REFERENCES}

1) Bartsch, H., and Montesano, R. (1984): Relevance of nitrosamines to human cancer. Carcinogenesis, 5, 1381-1393.

2) Lai, D. Y., and Arcos, J. C. (1980): Dialkylnitrosamine bioactivation and carcinogenesis. Life Sci., 27, 2149-2165.

3) Tu, Y. Y., and Yang, C. S. (1983): High-affinity nitrosamine dealkylase system in rat liver microsomes and its induction by fasting. Cancer Res., 43, 623-629.

4) Lorr, N. A., Tu, Y. Y., and Yang, C. S. (1982): The nature of nitrosamine denitrosation by rat liver microsomes. Carcinogenesis (Lond.), 3, 1039-1043. 
5) Yang, C. S., Tu, Y. Y., Koop, D. R., and Coon, M. J. (1985): Metabolism of nitrosamines by purified rabbit liver cytochrome P-450 isozymes. Cancer Res., 45, 1140-1145.

6) Jean, G. J., and Claude, H. (1975): Effects of chronic ethanol administration in the rat: Relative defendency on dietary lipids-I. Biochem. Pharmacol., 30, 1745-1751.

7) Rolf, T., Fernando, M., and Alexander, S. P. (1981): Hepatic microsomal ethanol oxidizing system (MEOS): Respective roles of ethanol and carbohydrates for the enhanced activity after chronic alcohol consumption. Biochem. Pharmacol., 30, 17451751.

8) Diane, F. B., and Gloria, H. S. (1982): Dietary amino acids and hepatic microsomal drug metabolism in syrian hamsters. Drug-Nutr. Interact., 1, 177-187.

9) Antal, M., Nagy, K., and Bedo, M. B. (1982): Effect of dietary protein and lipid on the activity of hepatic mixed-function oxidase system in young and adult rats. Ann. Nutr. Metab., 26, 393-399.

10) Diane, F. B., Dan, S. H., and Pamela, Y. B. (1983): Effects of dietary protein level on hepatic microsomal mixed-function oxidase systems during aging in two generations of syrian hamsters. Toxicol. Appl. Pharmacol., 68, 77-86.

11) Suzuki, H., Kaku, M., Hori, S., Hosono, M., and Kawano, S. (1988): Effects of soy protein isolate and exercise on dimethylnitrosamine demethylase activity by microsomal cytochrome P-450 system in SHR liver. Nutr. Sci. Soy Protein (in Japanese), 9, 25-32.

12) Lieber, C. S. (1988): The microsomal ethanol oxidizing system: its role in ethanol and xenobiotic metabolism. Biochem. Soc. Trans., 16, 232-239.

13) Amelizad, S., Appel, K. E., Schoepke, M., Ruhl, C. S., and Oesch, F. (1989): Enhanced demethylation and denitrosation of $N$-nitrosodimethylamine by human liver microsomes from alcoholics. Cancer Lett., 46, 43-49.

14) Maduagwu, E. N. (1989): Nitrosamine metabolism in protein-deficient weanling rats during the process of repletion. Ann. Nutr. Metab., 33, 49-56.

15) Suzuki, H., Kaku, M., Kajino, D., Hori, S., Hosono, M., Kawano, S., and Yoshio, M. (1989): Chronic administration of soy protein isolate and ethanol enhanced carcinogenic index on dimethylnitrosamine metabolism in the rabbit liver microsomes. Nutr. Sci. Soy Protein (in Japanese), 10, 39-44.

16) Ichihara, K., Yamakawa, I., Kusunose, E., and Kusunose, M. (1979): Fatty acid $\omega$ and ( $\omega$-1)-hydroxylation in rabbit intestinal mucosa microsomes. J. Biochem., 86, 139-146.

17) Kaku, M., Ichihara, K., Kusunose, E., Ogita, K., Yamamoto, S., Yano, I., and Kusunose, M. (1984): Purification and characterization of cytochrome P-450 specific for prostaglandin and fatty acid hydroxylase activities from the microsomes of rabbit small intestinal mucosa. J. Biochem., 96, 1883-1891.

18) Lowry, O. H., Rosebrough, N. J., Farr, A. L., and Randall, R. J. (1951): Protein measurement with the Folin phenol reagent. J. Biol. Chem., 193, 265-275.

19) Omura, T., and Sato, R. (1964): The carbon monoxide-binding pigment of liver microsomes: evidence for its hemoprotein nature. J. Biol. Chem., 239, 2370-2378.

20) Taniguchi, H., Imai, Y., Iyanagi, T., and Sato, R. (1979): Interaction between NADPH-cytochrome P-450 reductase and cytochrome P-450 in the membrane of phosphatidylcholine vesicles. Biochim. Biophys. Acta, 550, 341-356. 
21) Nash, T. (1953): The colorimetric estimation of formaldehyde by means of the Hantzsch reaction. Biochem. J., 55, 416-421.

22) Hildebrandt, A., and Estabrook, R. W. (1971): Evidence for the participation of cytochrome $b_{5}$ in hepatic microsomal mixed-function oxidation reactions. Arch. Biochem. Biophys., 143, 66-79.

23) Astrom, A., and Depierre, J. W. (1986): Rat liver microsomal cytochrome P-450 purification, characterization, multiplicity and induction. Biochim. Biophys. Acta, 853, $1-27$.

24) Hietanen, E., Laitinen, M., and Hanninen, O. (1982); Cytochrome P-450, Biochemistry, Biophysics and Environmental Implications. Elsevier Science Publishers, Amsterdam.

25) Kupfer, D., Navarro, J., and Piccolo, D. E. (1978): Hydroxylation of prostaglandins $\mathrm{A}_{1}$ and $\mathrm{E}_{1}$ by liver microsomal monoxygenase. J. Biol. Chem., 253, 2804-2811.

26) Navarro, J., Piccolo, D. E., and Kupfer, D. (1978): Hydroxylation of prostaglandin $\mathrm{E}_{1}$ by kidney cortex microsomal monooxygenase in the guinea pig. Arch. Biochem. Biophys., 191, 125-133.

27) Oliw, E. H., and Oates, J. A. (1981): Oxygenation of arachidonic acid by hepatic microsomes of the rabbit. Mechanism of biosynthesis of two vicinal dihydroxyeicosatrienoic acid. Biochim. Biophys. Acta, 666, 327-340.

28) Capdevia, J., Chacos, N., Werringloer, J., Prough, R. A., and Estabrook, R. W. (1981): Liver microsomal cytochrome P-450 and the oxidative metabolism of arachidonic acid. Proc. Natl. Acad. Sci. U.S.A., 78, 5362-5366.

29) Suzuki, H., Kaku, M., Hori, S., and Hosono, M. (1989): Two systems of microsomal P-450 linked dimethylnitrosamine demethylation with or without stimulation of arachidonic acid in rabbit gastric mucosa. Jpn. J. Physiol., 39 (suppl), 261.

30) Kaku, M., and Suzuki, H. (1988): Arachidonic acid dependent and independent monooxygenase pathways of dimethylnitrosamine demethylation in the microsomes of rabbit stomach mucosa. 2nd International ISSX Meeting, Xenobiotic Metabolism and Disposition, abstracts, 2-403. 